\title{
IMPACT OF SOIL SALINITY ON AVAILABLE MACRO NUTRIENTS UPTAKE BY WHEAT PLANT
}

\author{
Fatma El Agyzy and M. Aboukota \\ Department of Soil Chemical and Physical - \\ Soils, Water \& Environment Research Institute - Agriculture Research Center - Egypt \\ Aboukota.m@gmail.com
}

Received: Feb. 16, 2019

Accepted: Feb. 28,2019

\begin{abstract}
In Egypt, the soil salinity is the mainly constraint to the development of agricultural sector. In the last few decades, the farmers and the government have made a great effort to diminish the hazard of soil salinity. The resistance of soils to salinity processes by human positive actions is known as soil resilience. This study aims to assess the soil salinity and resilience at north of Nile Delta and evaluate their impact on macro nutrients uptake by wheat plant. To fulfill these objectives, (i) field survey for identifying the main soil physical and chemical properties as well as the nutrients status in soils of the study area were carried out, (ii) explore the effects of salinity on the macronutrients uptake and ionic relations, and to (iii) status of macronutrients in soils and wheat plant in salinity environments. The results showed that the textural classes of these soils were clay were determined in cultivated land. In addition, The CEC range between 26.49 to $33.03 \mathrm{Cmolc}^{-1}$, total $\mathrm{CaCO}_{3}$ was range between 0.91 to $3.04 \%$ and the gypsum was range between 1.69 to $5.64 \%$. The dominant soluble cations were $\mathrm{Na}^{+}$ followed by $\mathrm{Ca}^{+2}$ and $\mathrm{Mg}^{+2}$ while $\mathrm{K}^{+}$was rather low in a descending order. On the other hand, soluble anions were dominated by $\mathrm{Cl}^{-}$and $\mathrm{SO}_{4}{ }^{-2}$. Results on correlations of EC with macronutrients in the soils, it gives strong positively correlation and regression of EC constant with available macronutrients. The present study confirms that at all salinity levels the variation in germination, plant growth, dry matter accumulation, ionic strength and availability of nutrients in seeds and straw could be better explored in determining the tolerance capacity of the wheat cultivars.
\end{abstract}

Key words: Soil salinity, available macronutrients, wheat.

\section{INTRODUCTION}

Soil salinity is defined as the process, which lowers (quantitatively or qualitatively) the current and/or the potential suitability of soil to produce goods or services. Nutrient disturbances under both drought and salinity reduce plant growth by affecting the availability, transport and partitioning of nutrients. However, drought and salinity can differentially affect the mineral nutrition of plants (Hu and Schmidlter, 2005).

Salt affected soils occur commonly in arid and semi-arid regions and characterized by excessively high levels of water- soluble salts. In most cases, sodium chloride is a major salt contaminant in such soils, it has a small molecule size and when oxidized by water, produces $\mathrm{Na}+$ and $\mathrm{Cl}$ - ions, which are easily absorbed by the root cells of higher plants and transferred to the whole plant causing ionic and osmotic stresses at the cellular level of such plants (Rodriguez et al., 2006).

Salinity may cause nutrient deficiencies or imbalance because of the competition of more $\mathrm{Na}$ and $\mathrm{Cl}$ ions with nutrients such as $\mathrm{K}^{+}, \mathrm{Ca}^{2+}$ and $\mathrm{NO}_{3}$. Drought, on the other hand, can affect nutrient uptake and impair acropetal translocation of some nutrient. A better 
understanding of the role of mineral nutrient in plant resistance to drought and salinity will contribute to improve fertilizer management in arid and semiarid areas and in regions suffering from temporary drought (Hu et al., 2017).

Salt- affected soils can be classified according to how the salinity developed: primary salinity which occurs naturally where the soil parent materials rich in soluble salts or geochemical processes result in salt-affected soil. Secondary salinity is salinization of land and water resources due to human activities. Human activities which can induce salinization include poor irrigation management; insufficient drainage; improper cropping pattern sand rotations and chemical contamination (Oldeman, et al., 1990 and UNEP, 2007).

Wheat is moderately tolerant to salinity Genc et al., (2007), and its growth and physiological responses to salinity stress have been extensively studied (Saqib et al., 2005; Munns and Tester 2008; Saqib et al., 2013; Rahnama et al., 2011 and McDonald et al., 2015). However, the morpho-physiological responses of wheat to the combined effects of salinity and low macronutrients ( $N$, $P$ and $K$ ) have not been well understood.

To address these objectives, we used salinity-tolerant bread wheat (Triticum aestivum L.) cultivar Janz, which is Pinefficient (Osborne and Rengel 2002 and Zaicou et al., 2002) and salinity-sensitive durum wheat (Triticum turgidum L.) cultivar Jandaroi, which is also $P$ inefficient (Shamaya, 2014 and Schwenke et al., 2015). We hypothesized that wheat cultivars would respond differently to salinity and low macronutrients interaction, and the combined stress of low macronutrients and salinity would be more detrimental on these attributes than their individual effects.
The main objectives of this study were to: (i) Identifying the main soil physical and chemical properties as well as the nutrients status in soils of the study area, (ii) explore the effects of salinity on the macronutrients uptake and ionic relations, and to (iii) determine the macronutrients in soils and wheat plant in salinity environments.

\section{MATERIALS AND METHODS}

The study area is located at the north of the Nile Delta between latitude $32^{\circ} 10^{\prime}$ and $31^{\circ} 45^{\prime} \mathrm{N}$, and longitudes $30^{\circ} 27^{\prime}$ and $35^{\circ} 20^{\prime}$ E "Edko region- The governorate of Albehira". The collected soil samples represent 15 profiles with 2 depths (0$35 \mathrm{~cm}$ and $35-100 \mathrm{~cm}$ ) were illustrated in Map (1) air dried, crushed, sieved to pass a $2 \mathrm{~mm}$ sieve and preserved for further analyses and plant samples were taken for macronutrient analysis. The governorate of Albehira comes first as to fruits and vegetables production, and export of citrus, potatoes, tomatoes, artichoke, watermelon, string beans and pepper.

Soils analysis: Particle size distribution was estimated using the Pipette Method as described by Piper (1950). OM content was determined using the Walkley and Black according to the method outlined by Jackson, (1967). Soil pH was measured in 1:2.5 according to (Van Reeuwijk, 1993). CEC was determined by using sodium acetate at $\mathrm{pH} 8.2$ for saturation and ammonium acetate at $\mathrm{pH}$ 7.0 according to Bower et al., (1952). Gypsum content was measured according to Schoonover, (1952). CaCO3 content was measured according to Wright, (1939). ESP is calculated by the formula of Allison et al., (1954). EC is commonly used for indicating the total ionized concentration of solutions and soluble cations and anions according to Reitemerir, (1943). Available $\mathrm{N}$ and Available $\mathrm{K}$ were determined according to Page et al., (1982). Available $P$ was determined according to Olsen et al., (1954). 


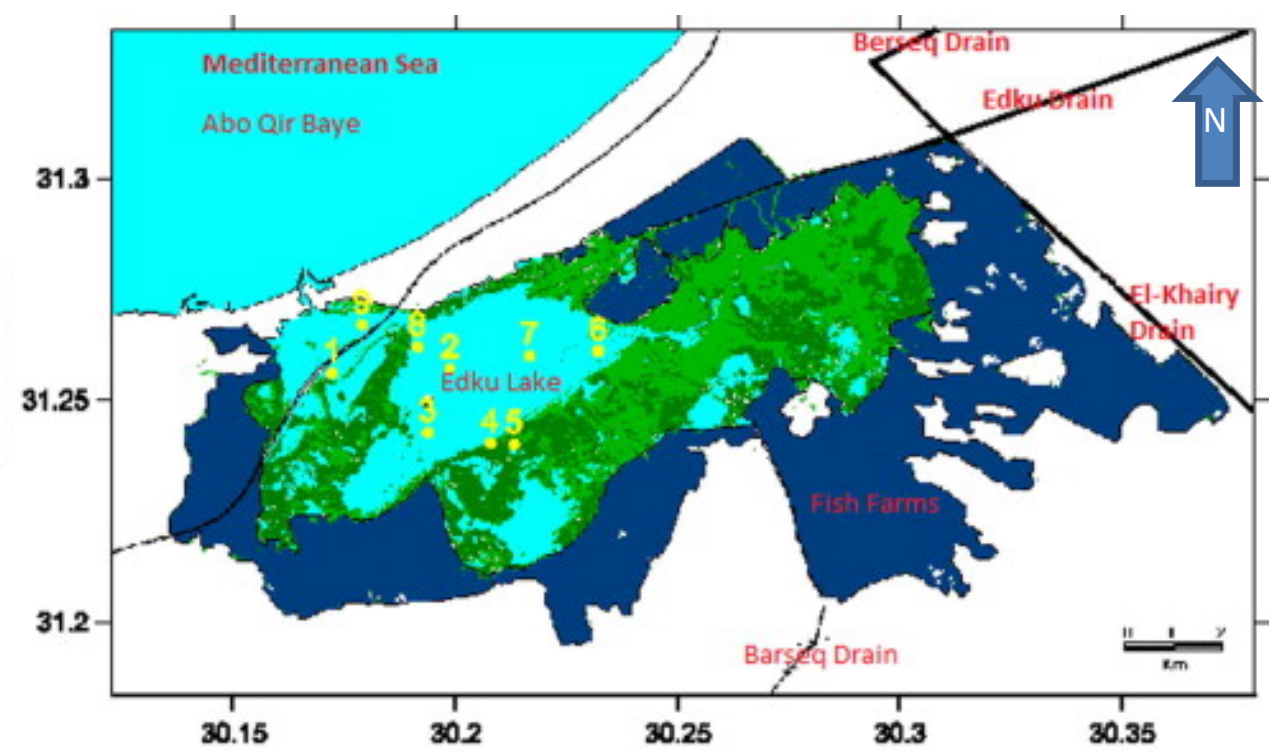

Map (1): The studied area for Edko region.

Plant analysis: available $\mathrm{N}$ was determined according to Chapman and Pratt, (1961), available P was determined according to Holman and Elliot, (1983), available $\mathrm{K}$ was determined according to Page et al., (1982).

Statically analysis: SPSS (version 20) and Microsoft Office Excel 2007 were used to determine the descriptive statistics and correlation analysis between soils and plant results. SPSS technology has made difficult analytical tasks easier through advances in usability and data access, enabling more people to benefit from the use of quantitative techniques in making decisions (SPSS, 2015), as following in Table (5). Correlation and regression analyses were carried out to detect functional relationship between soils and plant results.

\section{RESULTS AND DISCUSSION}

Particle size distribution: The soil separates (clay, silt and sand fractions) were significantly different cross the land use. Data in Table (1) reveal that the clay fraction content ranged between 66.23 to $89.01 \%$; and tends to increase with soil profiles depths. Considering the silt content, it was ranged between 9.89 to $33.00 \%$. In addition, it was shown the sand content varied between 0.32 to 2.13 $\%$. These results showed that the textural classes of these soils were clay. This may imply poor drainage cause to restrict effect on the yield potential of the studied area.

Some chemical properties: the results obtained, show that $\mathrm{Na}, \mathrm{Ca}, \mathrm{Mg}$ and $\mathrm{K}$ in the soils studied were high. The CEC range between 26.49 to $35.60 \mathrm{Cmolc} \mathrm{kg}^{-1}$ was high. As the soils were generally low in organic matter content, whereas OM range between 0.01 to $0.5 \%$. It is probable that the CEC obtained could be as results of the presence of high activity montmorillonitic 2:1 clay mineral. The results showed that total $\mathrm{CaCO}_{3}$ content was ranged between 0.91 to $3.04 \%$ Soil $\mathrm{CaCO}_{3}$ is identified as an important soil criterion for agricultural crops in the Mediterranean region. This criterion affects soil moisture regime and 
availability of nutrients to plants, $\mathrm{pH}$, and dispersion-flocculation and $O M$ stabilization. The gypsum values varied between 1.69 to $5.64 \%$ as shown in Table (1). The particular properties associated with gypsum imparts to soils affect to a great extent soil development including soil morphology accumulations of pedogenic gypsum which influences water holding capacity, nutrient, water availability for plants, root growth and the standard concepts of soil texture and rapture resistance.

Table (1): Particle size distribution, texture class and some chemical properties for the studied area:

\begin{tabular}{|c|c|c|c|c|c|c|c|c|c|}
\hline \multirow[b]{2}{*}{ Profiles } & \multirow[b]{2}{*}{$\begin{array}{l}\text { Depth } \\
\text { cm }\end{array}$} & \multicolumn{4}{|c|}{ Particle size distribution (\%) } & \multicolumn{4}{|c|}{ Soil chemical properties or $\mathrm{CaSO}_{4}$} \\
\hline & & Clay & Silt & Sand & Texture & $\begin{array}{c}\text { CEC } \\
(\mathrm{Cmolc} \\
\mathrm{kg}-1)\end{array}$ & $\begin{array}{l}\text { OM } \\
\%\end{array}$ & $\begin{array}{c}\mathrm{CaCO} 3 \\
\%\end{array}$ & $\begin{array}{c}\text { Gypsum } \\
\%\end{array}$ \\
\hline \multirow{2}{*}{1} & $0-35$ & 76.25 & 22.45 & 1.30 & Clay & 30.50 & 0.31 & 2.07 & 3.84 \\
\hline & $35-100$ & 77.91 & 21.77 & 0.32 & Clay & 31.16 & 0.08 & 2.00 & 3.72 \\
\hline \multirow{2}{*}{2} & $0-35$ & 69.58 & 28.95 & 1.47 & Clay & 27.83 & 0.35 & 2.66 & 4.95 \\
\hline & $35-100$ & 71.89 & 28.00 & 0.11 & Clay & 28.76 & 0.03 & 2.58 & 4.79 \\
\hline \multirow{2}{*}{3} & $0-35$ & 80.36 & 17.86 & 1.78 & Clay & 32.14 & 0.42 & 1.64 & 3.05 \\
\hline & $35-100$ & 89.01 & 9.89 & 1.10 & Clay & 35.60 & 0.26 & 0.91 & 1.69 \\
\hline \multirow{2}{*}{4} & $0-35$ & 78.90 & 20.00 & 1.10 & Clay & 31.56 & 0.26 & 1.84 & 3.42 \\
\hline & $35-100$ & 66.23 & 32.08 & 1.69 & Clay & 26.49 & 0.40 & 2.95 & 5.48 \\
\hline \multirow{2}{*}{5} & $0-35$ & 66.54 & 33.00 & 0.46 & Clay & 26.62 & 0.11 & 3.04 & 5.64 \\
\hline & $35-100$ & 71.20 & 26.87 & 1.93 & Clay & 28.48 & 0.45 & 2.47 & 4.59 \\
\hline \multirow{2}{*}{6} & $0-35$ & 68.63 & 30.37 & 1.00 & Clay & 27.45 & 0.24 & 2.79 & 5.19 \\
\hline & $35-100$ & 70.25 & 29.00 & 0.75 & Clay & 28.10 & 0.18 & 2.67 & 4.96 \\
\hline \multirow{2}{*}{7} & $0-35$ & 67.39 & 31.58 & 1.03 & Clay & 26.96 & 0.24 & 2.91 & 5.40 \\
\hline & $35-100$ & 70.00 & 29.85 & 0.15 & Clay & 28.00 & 0.04 & 2.75 & 5.10 \\
\hline \multirow{2}{*}{8} & $0-35$ & 70.85 & 29.00 & 0.15 & Clay & 28.34 & 0.04 & 2.67 & 4.96 \\
\hline & $35-100$ & 77.47 & 22.50 & 0.03 & Clay & 30.99 & 0.01 & 2.07 & 3.85 \\
\hline \multirow{2}{*}{9} & $0-35$ & 67.25 & 31.40 & 1.35 & Clay & 26.90 & 0.32 & 2.89 & 5.37 \\
\hline & $35-100$ & 67.88 & 31.11 & 1.01 & Clay & 27.15 & 0.24 & 2.86 & 5.32 \\
\hline \multirow{2}{*}{10} & $0-35$ & 74.00 & 24.58 & 1.42 & Clay & 29.60 & 0.33 & 2.26 & 4.20 \\
\hline & $35-100$ & 74.98 & 24.51 & 0.51 & Clay & 29.99 & 0.12 & 2.25 & 4.19 \\
\hline \multirow{2}{*}{11} & $0-35$ & 80.25 & 19.00 & 0.75 & Clay & 32.10 & 0.18 & 1.75 & 3.25 \\
\hline & $35-100$ & 82.58 & 16.89 & 0.53 & Clay & 33.03 & 0.12 & 1.55 & 2.89 \\
\hline \multirow{2}{*}{12} & $0-35$ & 78.58 & 20.25 & 1.17 & Clay & 31.43 & 0.28 & 1.86 & 3.46 \\
\hline & $35-100$ & 80.00 & 17.87 & 2.13 & Clay & 32.00 & 0.50 & 1.64 & 3.05 \\
\hline \multirow{2}{*}{13} & $0-35$ & 69.37 & 30.00 & 0.63 & Clay & 27.75 & 0.15 & 2.76 & 5.13 \\
\hline & $35-100$ & 70.48 & 29.00 & 0.52 & Clay & 28.19 & 0.12 & 2.67 & 4.96 \\
\hline \multirow{2}{*}{14} & $0-35$ & 75.44 & 23.54 & 1.02 & Clay & 30.18 & 0.24 & 2.17 & 4.02 \\
\hline & $35-100$ & 76.85 & 22.37 & 0.78 & Clay & 30.74 & 0.18 & 2.06 & 3.82 \\
\hline \multirow{2}{*}{15} & $0-35$ & 80.00 & 18.10 & 1.90 & Clay & 32.00 & 0.45 & 1.67 & 3.09 \\
\hline & $35-100$ & 81.69 & 17.00 & 1.31 & Clay & 32.68 & 0.31 & 1.56 & 2.91 \\
\hline
\end{tabular}


Impact of soil salinity on available macro nutrients uptake by wheat plant

Soils pH classification: in the present study most soils profiles have a pH in the values ranged of 8.18 to 8.76 ; indicating that these soils were slightly to moderately alkaline and most of soil $\mathrm{pH}$ is represented the presence of strong concentration of neutral soluble salts. Soil $\mathrm{pH}$ concentration is shown in Table (2) and it explains that more concentration is in northeastern part of the study area. Soil pH can affect CEC and $A E C$ by altering the surface charge of colloids. A higher concentration of $\mathrm{H}^{+}$ (lower pH) will neutralize the negative charge on colloids, thereby decreasing CEC and increasing AEC. The opposite occurs when $\mathrm{pH}$ increases.

Table (2): Status of pH soil, EC and soluble cations \& anions for the studied area.

\begin{tabular}{|c|c|c|c|c|c|c|c|c|c|c|c|}
\hline \multirow[t]{2}{*}{ Profiles } & \multirow{2}{*}{$\begin{array}{c}\text { Depth } \\
\text { cm }\end{array}$} & \multirow{2}{*}{$\begin{array}{c}\mathrm{pH} \\
\text { soil } \\
(1: 2.5)\end{array}$} & \multirow{2}{*}{$\begin{array}{c}\text { EC } \\
\mathrm{dS} \mathbf{m}^{-1}\end{array}$} & \multicolumn{4}{|c|}{$\begin{array}{l}\text { Soluble cations } \\
(\text { (mmolc L-1) }\end{array}$} & \multicolumn{3}{|c|}{$\begin{array}{l}\text { Soluble anions } \\
\left(\mathrm{mmolc}^{-1}\right)\end{array}$} & \multirow{2}{*}{$\begin{array}{c}\text { ESP } \\
\%\end{array}$} \\
\hline & & & & $\mathrm{Ca}^{2+}$ & $\mathrm{Mg}^{2+}$ & $\mathrm{K}^{+}$ & $\mathrm{Na}^{+}$ & $\mathrm{Cl}^{-}$ & $\mathrm{HCO}_{3}{ }^{-}$ & $\mathrm{SO}_{4}{ }^{2-}$ & \\
\hline \multirow{2}{*}{1} & $0-35$ & 8.55 & 8.84 & 22.89 & 18.91 & 0.59 & 46.00 & 65.32 & 1.84 & 21.22 & 4.03 \\
\hline & $35-100$ & 8.52 & 8.57 & 21.39 & 17.68 & 3.64 & 43.00 & 61.06 & 1.79 & 22.86 & 3.85 \\
\hline \multirow{2}{*}{2} & $0-35$ & 8.68 & 11.40 & 29.11 & 24.06 & 2.28 & 58.52 & 83.10 & 2.38 & 28.50 & 4.71 \\
\hline & $35-100$ & 8.67 & 11.02 & 28.56 & 23.61 & 0.66 & 57.41 & 81.52 & 2.30 & 26.41 & 4.65 \\
\hline \multirow{2}{*}{3} & $0-35$ & 8.41 & 7.03 & 17.24 & 14.25 & 4.16 & 34.66 & 49.22 & 1.47 & 19.63 & 3.33 \\
\hline & $35-100$ & 8.18 & 3.89 & 9.45 & 7.81 & 2.67 & 19.00 & 26.98 & 0.81 & 11.14 & 2.13 \\
\hline & $0-35$ & 8.47 & 7.87 & 19.53 & 16.14 & 3.82 & 39.25 & 55.74 & 1.64 & 21.36 & 3.62 \\
\hline & $35-100$ & 8.74 & 12.63 & 32.34 & 26.73 & 2.24 & 65.00 & 92.30 & 2.64 & 31.36 & 5.03 \\
\hline & $0-35$ & 8.76 & 12.99 & 33.01 & 27.28 & 3.28 & 66.35 & 94.22 & 2.71 & 32.99 & 5.09 \\
\hline & $35-100$ & 8.65 & 10.58 & 27.47 & 22.70 & 0.41 & 55.21 & 78.40 & 2.21 & 25.18 & 4.53 \\
\hline & $0-35$ & 8.70 & 11.96 & 29.98 & 24.77 & 4.57 & 60.25 & 85.56 & 2.49 & 31.52 & 4.79 \\
\hline & $35-100$ & 8.68 & 11.42 & 29.17 & 24.11 & 2.27 & 58.63 & 83.25 & 2.38 & 28.54 & 4.71 \\
\hline \multirow[b]{2}{*}{$y$} & $0-35$ & 8.72 & 12.43 & 31.11 & 25.71 & 4.96 & 62.54 & 88.81 & 2.59 & 32.93 & 4.91 \\
\hline & $35-100$ & 8.71 & 11.75 & 30.35 & 25.08 & 1.09 & 61.00 & 86.62 & 2.45 & 28.45 & 4.83 \\
\hline \multirow[b]{2}{*}{$\varepsilon$} & $0-35$ & 8.68 & 11.42 & 29.02 & 23.99 & 2.82 & 58.34 & 82.84 & 2.38 & 28.95 & 4.70 \\
\hline & $35-100$ & 8.53 & 8.86 & 22.06 & 18.23 & 3.95 & 44.34 & 62.96 & 1.85 & 23.77 & 3.93 \\
\hline & $0-35$ & 8.72 & 12.36 & 31.30 & 25.87 & 3.55 & 62.91 & 89.33 & 2.58 & 31.71 & 4.93 \\
\hline & $35-100$ & 8.73 & 12.25 & 31.59 & 26.11 & 1.28 & 63.50 & 90.17 & 2.56 & 29.75 & 4.95 \\
\hline \multirow{2}{*}{10} & $0-35$ & 8.59 & 9.68 & 24.80 & 20.49 & 1.64 & 49.84 & 70.77 & 2.02 & 23.98 & 4.24 \\
\hline & $35-100$ & 8.60 & 9.65 & 24.99 & 20.65 & 0.64 & 50.22 & 71.31 & 2.01 & 23.17 & 4.26 \\
\hline \multirow{2}{*}{11} & $0-35$ & 8.46 & 7.48 & 19.13 & 15.81 & 1.41 & 38.45 & 54.60 & 1.56 & 18.64 & 3.57 \\
\hline & $35-100$ & 8.40 & 6.65 & 16.85 & 13.93 & 1.85 & 33.87 & 48.10 & 1.39 & 17.01 & 3.28 \\
\hline \multirow{2}{*}{12} & $0-35$ & 8.50 & 7.97 & 20.66 & 17.07 & 0.48 & 41.52 & 58.96 & 1.66 & 19.10 & 3.76 \\
\hline & $35-100$ & 8.44 & 7.04 & 18.24 & 15.08 & 0.36 & 36.67 & 52.07 & 1.47 & 16.82 & 3.46 \\
\hline \multirow{2}{*}{13} & $0-35$ & 8.70 & 11.81 & 30.02 & 24.81 & 2.94 & 60.34 & 85.68 & 2.46 & 29.96 & 4.80 \\
\hline & $35-100$ & 8.68 & 11.42 & 29.28 & 24.20 & 1.85 & 58.85 & 83.57 & 2.38 & 28.22 & 4.72 \\
\hline \multirow{2}{*}{14} & $0-35$ & 8.57 & 9.27 & 23.81 & 19.67 & 1.35 & 47.85 & 67.95 & 1.93 & 22.80 & 4.13 \\
\hline & $35-100$ & 8.54 & 8.81 & 22.44 & 18.54 & 1.99 & 45.10 & 64.04 & 1.84 & 22.19 & 3.98 \\
\hline & $0-35$ & 8.45 & 7.13 & 18.46 & 15.26 & 0.43 & 37.11 & 52.70 & 1.49 & 17.08 & 3.49 \\
\hline & $35-100$ & 8.42 & 6.69 & 17.30 & 14.30 & 0.55 & 34.78 & 49.39 & 1.40 & 16.15 & 3.34 \\
\hline
\end{tabular}


Soil electrical conductivity (EC): EC is a useful indicator in managing agricultural system. In actuality, the interpretation of EC of a soil or media must be made considering the plant to be grown. EC is an electrolytic process that takes place principally through water filled pores. Cations $\left(\mathrm{Na}^{+}, \mathrm{Ca}^{2+}, \mathrm{Mg}^{2+}\right.$ and $\mathrm{K}^{+}$) and anions $\left(\mathrm{Cl}, \mathrm{SO}_{4}\right.$ and $\left.\mathrm{HCO}_{3}\right)$ from salts dissolved in soil water carry electrical charges and conduct the electrical current. Consequently, the concentration of ions determines the EC of soils. In the soils profiles studied, an EC values ranged of 3.89 to $12.63 \mathrm{dS} \mathrm{m}^{-1}$ (Table 2), indicating that the studied soils were very slightly saline to moderately saline. The results presented that high concentration is in (Edko region) of the study area. The highest ESP values were associated with high salinity and dominance of soluble sodium in the soil extract. Soluble cations were dominated by $\mathrm{Na}^{+}$followed by $\mathrm{Ca}^{+2}$ and $\mathrm{Mg}^{+2}$ while soluble $\mathrm{K}^{+}$ion was rather low in a descending order. On the other hand, soluble anions were dominated by $\mathrm{Cl}^{-}$ and $\mathrm{SO}_{4}{ }^{-2}$. High concentrations of neutral salts, such as $\mathrm{NaCl}$ and $\mathrm{Na}_{2} \mathrm{SO}_{4}$ may interfere with the absorption of water by plants because the osmotic pressure in the soil solution is nearly as high as or higher than that in the plant cells.

Available macro nutrients in soils: Macronutrients are of great the importance in controlling yield of crops.

Soil characterization in relation to evaluation of macronutrients status of the soils of an area or regions is an important aspect in the context of sustainable agriculture production.

Available $\mathbf{N}$ status varied from 33.46 to $116.83 \mathrm{~m} \mathrm{~kg} \mathrm{k}^{-1}$; on the basis of the rating suggested by Lindsay and Norvell (1978), $60 \%$ of the soil samples were found to be high ( 97.21 to $116.83 \mathrm{mg} \mathrm{kg}^{-1}$ ), $36 \%$ of the soils samples were found to be medium $\left(61.03\right.$ to $\left.79.70 \mathrm{mg} \mathrm{kg}^{-1}\right)$. On the other hand, Available P status varied from 4.16 to $7.77 \mathrm{mg} \mathrm{kg}^{-1}, 100 \%$ of the soil samples were found to be medium.

Available K status varied from 215.84 to $753.74 \mathrm{mg} \mathrm{kg}^{-1}, 100 \%$ of the soil samples were found to be high, as it is in shown Table (3). The relatively high available $K$ amounts in the layers of the Nile alluvial sediments could be mainly attributed to the relatively high content of bound K-organic and K-exchangeable fractions (Aboukota, 2012 and 2016). I am interpret the higher content of available nutrients may be attributed to the higher application of NPK fertilizers on the tested soil.

Activates of macro nutrients in the soil solution are affected by high concentration of salts ions, usually $\mathrm{Na}^{+}$ and $\mathrm{Cl}^{-}$, resulting in a nutritional disorder in plants. Attention should be paid to the different ways of ions getting to the roots of plants. Three mechanisms are known in which nutrients reach the root surface, a prerequisite for nutrient uptake. These mechanisms are called root interception, mass flow and diffusion movement. Rates among these three mechanisms are variable, related to the chemical characteristics and behavior of the nutrient elements in soils.

The results indicated that $\mathrm{N}$ content status varied from 0.07 to $1.55 \%$ in wheat seeds and 0.14 to $1.69 \%$ in wheat straw; the $\mathrm{N}$ content is in some samples low. In adding, the $P$ content at the level of profiles taken from the studied area is low, whereas range between 0.20 to $0.69 \%$ in seeds and in straw range between 0.15 to $0.34 \%$. Except for profile No. 1 , the results showed that the $P$ rate in seeds both samples were sufficient. In addition, the wheat content of $K$ is low in seeds and straw. Whereas range between 0.01 to $1.04 \%$ in seeds and in straw range between 0.66 to1.23\%. 
Impact of soil salinity on available macro nutrients uptake by wheat plant

Table (3): Status of available macro nutrients for soil studied area.

\begin{tabular}{|c|c|c|c|c|c|c|c|}
\hline \multirow[t]{2}{*}{ Profiles } & \multirow{2}{*}{$\begin{array}{l}\text { Depth } \\
\text { cm }\end{array}$} & \multicolumn{6}{|c|}{$\begin{array}{l}\text { Available Macro- Nutrients } \\
\qquad\left(\mathrm{mg} \mathrm{kg}^{-1}\right)\end{array}$} \\
\hline & & $\mathrm{N}$ & class & $\mathbf{P}$ & class & $\mathrm{K}$ & class \\
\hline \multirow{2}{*}{1} & $0-35$ & 81.00 & High & 6.47 & Medium & 522.56 & High \\
\hline & $35-100$ & 75.71 & Medium & 6.25 & Medium & 488.48 & High \\
\hline \multirow{2}{*}{2} & $0-35$ & 103.04 & High & 7.30 & Medium & 664.79 & High \\
\hline & $35-100$ & 101.09 & High & 7.23 & Medium & 652.18 & High \\
\hline \multirow{2}{*}{3} & $0-35$ & 61.03 & Medium & 5.61 & Medium & 393.74 & High \\
\hline & $35-100$ & 33.46 & Low & 4.16 & Medium & 215.84 & High \\
\hline \multirow{2}{*}{4} & $0-35$ & 69.11 & Medium & 5.97 & Medium & 445.88 & High \\
\hline & $35-100$ & 114.45 & High & 7.69 & Medium & 738.40 & High \\
\hline \multirow{2}{*}{5} & $0-35$ & 116.83 & High & 7.77 & Medium & 753.74 & High \\
\hline & $35-100$ & 97.21 & High & 7.09 & Medium & 627.19 & High \\
\hline \multirow{2}{*}{6} & $0-35$ & 106.09 & High & 7.40 & Medium & 684.44 & High \\
\hline & $35-100$ & 103.24 & High & 7.30 & Medium & 666.04 & High \\
\hline \multirow{2}{*}{7} & $0-35$ & 110.12 & High & 7.54 & Medium & 710.45 & High \\
\hline & $35-100$ & 107.41 & High & 7.45 & Medium & 692.96 & High \\
\hline \multirow{2}{*}{8} & $0-35$ & 102.73 & High & 7.28 & Medium & 662.74 & High \\
\hline & $35-100$ & 78.07 & Medium & 6.35 & Medium & 503.70 & High \\
\hline \multirow{2}{*}{9} & $0-35$ & 110.77 & High & 7.56 & Medium & 714.66 & High \\
\hline & $35-100$ & 111.81 & High & 7.60 & Medium & 721.36 & High \\
\hline \multirow{2}{*}{10} & $0-35$ & 87.76 & High & 6.73 & Medium & 566.18 & High \\
\hline & $35-100$ & 88.43 & High & 6.76 & Medium & 570.50 & High \\
\hline \multirow{2}{*}{11} & $0-35$ & 67.70 & Medium & 5.91 & Medium & 436.79 & High \\
\hline & $35-100$ & 59.64 & Medium & 5.55 & Medium & 384.76 & High \\
\hline \multirow{2}{*}{12} & $0-35$ & 73.11 & Medium & 6.15 & Medium & 471.67 & High \\
\hline & $35-100$ & 64.57 & Medium & 5.78 & Medium & 416.57 & High \\
\hline \multirow{2}{*}{13} & $0-35$ & 106.25 & High & 7.41 & Medium & 685.46 & High \\
\hline & $35-100$ & 103.62 & High & 7.32 & Medium & 668.54 & High \\
\hline \multirow{2}{*}{14} & $0-35$ & 84.25 & High & 6.60 & Medium & 543.58 & High \\
\hline & $35-100$ & 79.41 & Medium & 6.40 & Medium & 512.34 & High \\
\hline \multirow{2}{*}{15} & $0-35$ & 65.34 & Medium & 5.81 & Medium & 421.57 & High \\
\hline & $35-100$ & 61.24 & Medium & 5.62 & Medium & 395.10 & High \\
\hline
\end{tabular}

*Note: AV. ${ }^{*}=$ available, Clas. ${ }^{*}=$ classification. Critical level of the studied available plant nutrients (mg/kg), after Lindsay and Norvell (1978), [ $\mathrm{N}<40.0$ Low, 40.0-80.0 Medium, $>80.0$ High; $\mathrm{P}<5.0$ Low, 5.0-10.0 Medium, >10.0 High; K<85.0 Low, 85.0-170.0 Medium; >170.0 High].

The analysis of variance revealed a significant difference between salinity levels, in terms of macronutrients accumulation in the plants. The $\mathrm{N}, \mathrm{P}$ and $K$ contents in plants showed a higher level of salinity (Table 4). 
Table (4): Status of macro nutrients to seeds and straw for wheat plant in the studied area.

\begin{tabular}{|c|c|c|c|c|c|c|c|}
\hline \multirow[t]{2}{*}{ Profiles } & \multirow[t]{2}{*}{ Depth cm } & \multicolumn{3}{|c|}{$\begin{array}{l}\text { Macro- Nutrients concentration } \\
\text { in seeds } \\
(\%)\end{array}$} & \multicolumn{3}{|c|}{$\begin{array}{l}\text { Macro- Nutrients concentration } \\
\text { in straw } \\
(\%)\end{array}$} \\
\hline & & $\mathbf{N}$ & $\mathbf{P}$ & $\mathrm{K}$ & $\mathbf{N}$ & $\mathbf{P}$ & $\mathrm{K}$ \\
\hline \multirow{2}{*}{1} & & 1.01 Low & 0.69 Medium & 0.78 Low & 1.15 Low & 0.34 Low & 1.03 Low \\
\hline & & 0.93 Low & 0.66 Medium & 0.72 Low & 1.06 Low & 0.32 Low & 0.99 Low \\
\hline \multirow{2}{*}{2} & & 1.35 Low & 0.47 Low & 0.01 Low & 1.52 Low & 0.24 Low & 1.16 Low \\
\hline & & 1.32 Low & 0.44 Low & 0.99 Low & 1.49 Low & 0.23 Low & 1.15 Low \\
\hline \multirow{2}{*}{3} & & 0.66 Low & 0.37 Low & 0.54 Low & 0.78 Low & 0.25 Low & 0.89 Low \\
\hline & & 0.07 Low & 0.37 Low & 0.14 Low & 0.14 Low & 0.28 Low & 0.66 Low \\
\hline \multirow{2}{*}{4} & & 0.81 Low & 0.52 Low & 0.64 Low & 0.94 Low & 0.29 Low & 0.95 Low \\
\hline & ample 2 & 1.51 Low & 0.46 Low & 0.11 Low & 1.69 Low & 0.28 Low & 1.22 Low \\
\hline \multirow{2}{*}{5} & & 1.55 Low & 0.27 Low & 0.14 Low & 0.72 Low & 0.19 Low & 1.23 Low \\
\hline & le 2 & 1.27 Low & 0.22 Low & 0.95 Low & 1.42 Low & 0.22 Low & 1.12 Low \\
\hline \multirow{2}{*}{6} & Sample 1 & 1.40 Low & 0.22 Low & 0.04 Low & 1.56 Low & 0.25 Low & 1.17 Low \\
\hline & Sample 2 & 1.36 Low & 0.20 Low & 0.01 Low & 1.52 Low & 0.24 Low & 1.16 Low \\
\hline \multirow{2}{*}{7} & & 1.45 Low & 0.44 Low & 0.07 Low & 1.62 Low & 0.17 Low & 1.20 Low \\
\hline & Sample 2 & 1.42 Low & 0.32 Low & 0.05 Low & 1.58 Low & 0.16 Low & 1.18 Low \\
\hline \multirow{2}{*}{8} & & 1.35 Low & 0.37 Low & 0.60 Low & 1.51 Low & 0.24 Low & 1.15 Low \\
\hline & Sample 2 & 0.97 Low & 0.28 Low & 0.75 Low & 1.10 Low & 0.23 Low & 1.01 Low \\
\hline \multirow{2}{*}{9} & & 1.46 Low & 0.34 Low & 0.08 Low & 1.63 Low & 0.17 Low & 1.20 Low \\
\hline & & 1.48 Low & 0.30 Low & 0.09 Low & 1.65 Low & 0.17 Low & 1.20 Low \\
\hline \multirow{2}{*}{10} & le 1 & 1.12 Low & 0.43 Low & 0.85 Low & 1.27 Low & 0.27 Low & 1.07 Low \\
\hline & & 1.13 Low & 0.33 Low & 0.86 Low & 1.28 Low & 0.28 Low & 1.07 Low \\
\hline \multirow{2}{*}{11} & Sample 1 & 0.79 Low & 0.41 Low & 0.63 Low & 0.91 Low & 0.28 Low & 0.94 Low \\
\hline & ole 2 & 0.64 Low & 0.46 Low & 0.53 Low & 0.75 Low & 0.24 Low & 0.88 Low \\
\hline \multirow{2}{*}{12} & Sample 1 & 0.88 Low & 0.44 Low & 0.69 Low & 1.01 Low & 0.21 Low & 0.97 Low \\
\hline & & 0.73 Low & 0.49 Low & 0.59 Low & 0.85 Low & 0.16 Low & 0.92 Low \\
\hline \multirow{2}{*}{13} & Sample 1 & 1.40 Low & 0.34 Low & 1.04 Low & 1.57 Low & 0.25 Low & 1.17 Low \\
\hline & Sample 2 & 1.36 Low & 0.39 Low & 1.01 Low & 1.53 Low & 0.24 Low & 1.16 Low \\
\hline \multirow{2}{*}{14} & & 1.07 Low & 0.41 Low & 0.81 Low & 1.21 Low & 0.26 Low & 1.05 Low \\
\hline & & 0.99 Low & 0.38 Low & 0.76 Low & 1.13 Low & 0.24 Low & 1.02 Low \\
\hline \multirow{2}{*}{15} & & 0.74 Low & 0.40 Low & 0.60 Low & 0.87 Low & 0.17 Low & 0.92 Low \\
\hline & Sample 2 & 0.67 Low & 0.37 Low & 0.55 Low & 0.78 Low & 0.15 Low & 0.89 Low \\
\hline \multicolumn{8}{|l|}{ otes: } \\
\hline & $0.400-r$ & $\mathbf{P} \%$ * & ${ }^{*} 2.29=\mathrm{P}_{2} \mathrm{O}_{5}$ & $\mathrm{~K}_{2} \mathrm{O} \%$ & $0 * 0.83=\mathrm{K}$ & K \% & $1.2=\mathrm{K}_{2} \mathrm{O}$ \\
\hline
\end{tabular}


Impact of soil salinity on available macro nutrients uptake by wheat plant

$\%$

Relationship between Ec (dS/m) and available $N$ in the studied soils: the results relating correlation revealed that the available $N\left(r=0.784^{\star *}\right)$ were positively highly significantly correlated with EC (Table 5 \& Figure 1). In addition to this, with the increase of soil EC, increase available $\mathrm{N}$ in soil observed, might be the reason for such kind of results; the high degree of soil salinity affects the restriction of available $\mathrm{N}$ in the soil.

Relationship between Ec (dS/m) and available $P$ in soil: the results regarding correlation and regression showed that the available $P\left(r=0.871^{\star *}\right)$ were highly significant and positive in correlation with EC. Similar, relationships of available $P$ in coastal plain soils of Edko region - Albehira Governorate\} and \{Abbis region - Alex. Governorate\}, reported by (Aboukota 2012 and 2016).

Relationship between EC (dS/m) and available $K$ in soil: the results involving correlation revealed that the available $K$ $\left(r=0.888^{\star *}\right)$ were highly significantly and positively correlated with EC in soils.

Results on correlations of EC with NPK in the soils are graphically shown in Fig. (1). It gives strong positively correlation and regression of EC constant with available macronutrients such as $\left(N-R^{2}=0.896 ; P-R^{2}=0.871 ; K-\right.$ $\left.R^{2}=0.897\right)$.

Table (5): Correlation and regression between EC and macro nutrients in soil and wheat plant (seed and straw), and accuracy of statistical analysis.

\begin{tabular}{|c|c|c|c|c|c|c|c|}
\hline \multicolumn{8}{|c|}{$\begin{array}{l}\text { The independent variable is } \mathrm{EC} \mathrm{dS} / \mathrm{m} \text { with Dependent Variable: } \mathrm{N} \text { soil, } \mathrm{P} \text { soil, } \mathrm{K} \\
\text { soil, } \mathrm{N} \text { seed plant, } \mathrm{P} \text { seed plant, } \mathrm{K} \text { seed plant, } \mathrm{N} \text { straw plant, } \mathrm{P} \text { straw plant and } \mathrm{K} \\
\text { straw plant }\end{array}$} \\
\hline \multirow[b]{2}{*}{ Equation } & \multicolumn{4}{|c|}{ Model Summary } & \multicolumn{3}{|c|}{ Parameter Estimates } \\
\hline & $\begin{array}{c}\mathbf{R} \\
\text { Square }\end{array}$ & $\mathbf{F}$ & df1 & df2 & Constant & b1 & $r$ \\
\hline Linear $\mathbf{N}$ soil & 0.897 & 8104.641 & 1 & 28 & -0.678 & 9.093 & $0.784^{\star *}$ \\
\hline Linear P soil & 0.871 & 929.356 & 1 & 28 & - 83.705 & 76.455 & $0.871^{* *}$ \\
\hline Linear K soil & 0.897 & 4255.623 & 2 & 27 & -5.544 & 10.226 & $0.888^{* *}$ \\
\hline Linear $\mathrm{N}$ seed & 0.857 & 620.781 & 1 & 28 & 27.061 & 0.118 & $0.783^{* *}$ \\
\hline Linear P seed & 0.857 & 620.781 & 1 & 28 & 0.037 & 0.889 & $0.773^{* *}$ \\
\hline Linear $\mathrm{K}$ seed & 0.854 & 1147.365 & 1 & 28 & 0.658 & 11.369 & $0.893^{* *}$ \\
\hline Linear N straw & 0.858 & 457.365 & 1 & 28 & 0.251 & 5.297 & $0.813^{\star \star}$ \\
\hline Linear P straw & 0.867 & 754.635 & 1 & 28 & -6.632 & 5.638 & $0.873^{* *}$ \\
\hline Linear K straw & 0.863 & 749.986 & 1 & 28 & -4.362 & 12.254 & $0.777^{\star *}$ \\
\hline
\end{tabular}




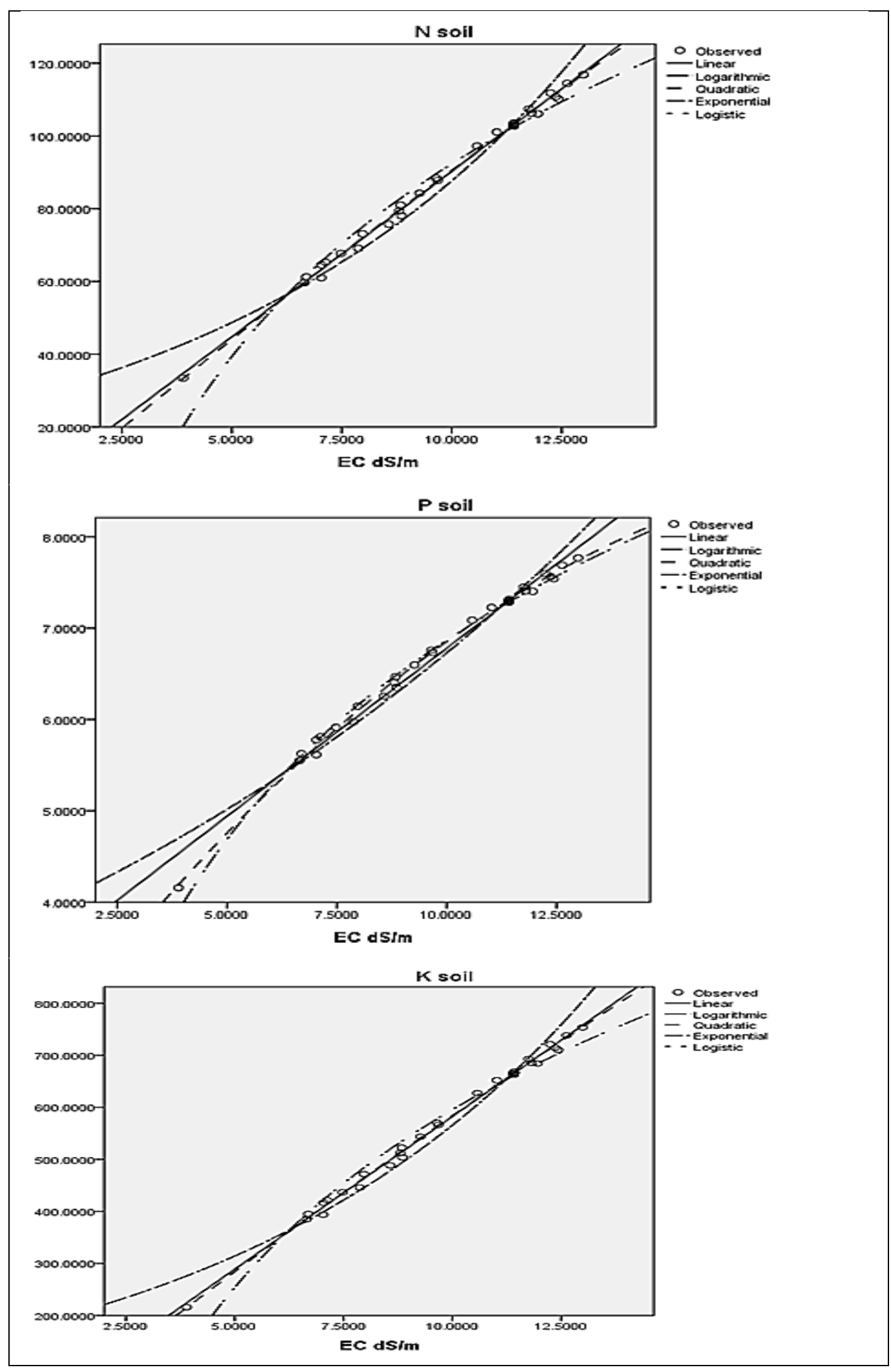

Figure (1): Relationship between Ec (dS/m) and available $\mathrm{N}, \mathrm{P}, \mathrm{K} \mathrm{mg} \mathrm{kg}^{-1}$ in soils. 
These results clearly indicate the frequency depended of correlation coefficient of electric constant of soils with their available macronutrients.

The increase of available $\mathrm{N}$ with higher salinity may be ascribed to the inhibition effect of salinity on the microbial activity of nitrogen transformation in the soil and its loosing for the soil consequently promote its residual amount in the soil. The residual ammonium in the soil may be fixed with the clay mineral consequently enhanced its availability in the soil. Soil salinity is a major limitation to crops production in many areas to the world. Salinity is a wide spread environmental stress for crop plants in arid and coastal regions.

Relationship between EC (dS/m) and available $\mathrm{N}, \mathrm{P}$ and $\mathrm{K} \mathrm{mg} \mathrm{kg}^{-1}$ in seeds: the results relating correlation revealed that the available $N\left(r=0.783^{* \star}\right), P\left(r=0.773^{\star *}\right)$ and $K\left(r=0.893^{\star *}\right)$ were highly positively significantly correlated with EC (Table 5 \& Figure 2). It gives strong positively correlation and regression of EC constant with available macronutrients in seeds such as $\left(N-R^{2}=0.857 ; P-R^{2}=\right.$
$0.857 ; \mathrm{K}-\mathrm{R}^{2}=0.854$ ). Prakash et al., (2010) found that height and weight of all cultivars were less affected by the salt stress, under field visit. Seed germination, seedling emergence and their survival are particularly sensitive to substrate salinity.

The present study confirms that at all salinity levels the variation in NPK CONTENT, ionic and availability nutrition could be better explored in determining the tolerance capacity of the wheat cultivars. Relationship between Ec (dS/m) and available $\mathrm{N}, \mathrm{P}$ and $\mathrm{K} \mathrm{mg} \mathrm{kg}^{-1}$ in straw: the results relating correlation revealed that the available $N\left(r=0.813^{\star *}\right), P(r=$ $\left.0.873^{\star *}\right)$ and $K\left(r=0.777^{* *}\right)$ were highly significantly and positively correlated with EC (Table 5 \& Figure 3). It gives strong positively correlation and regression of EC constant with available macronutrients in seeds recorded as ( $\mathrm{N}$ $R^{2}=0.858 ; P-R^{2}=0.867 ; K-R^{2}=0.863$ ). Due to increasing salt salinity large areas of arable land are being removed from crop production every year (Chapman, 1975 and Epstein et al., 1980). 


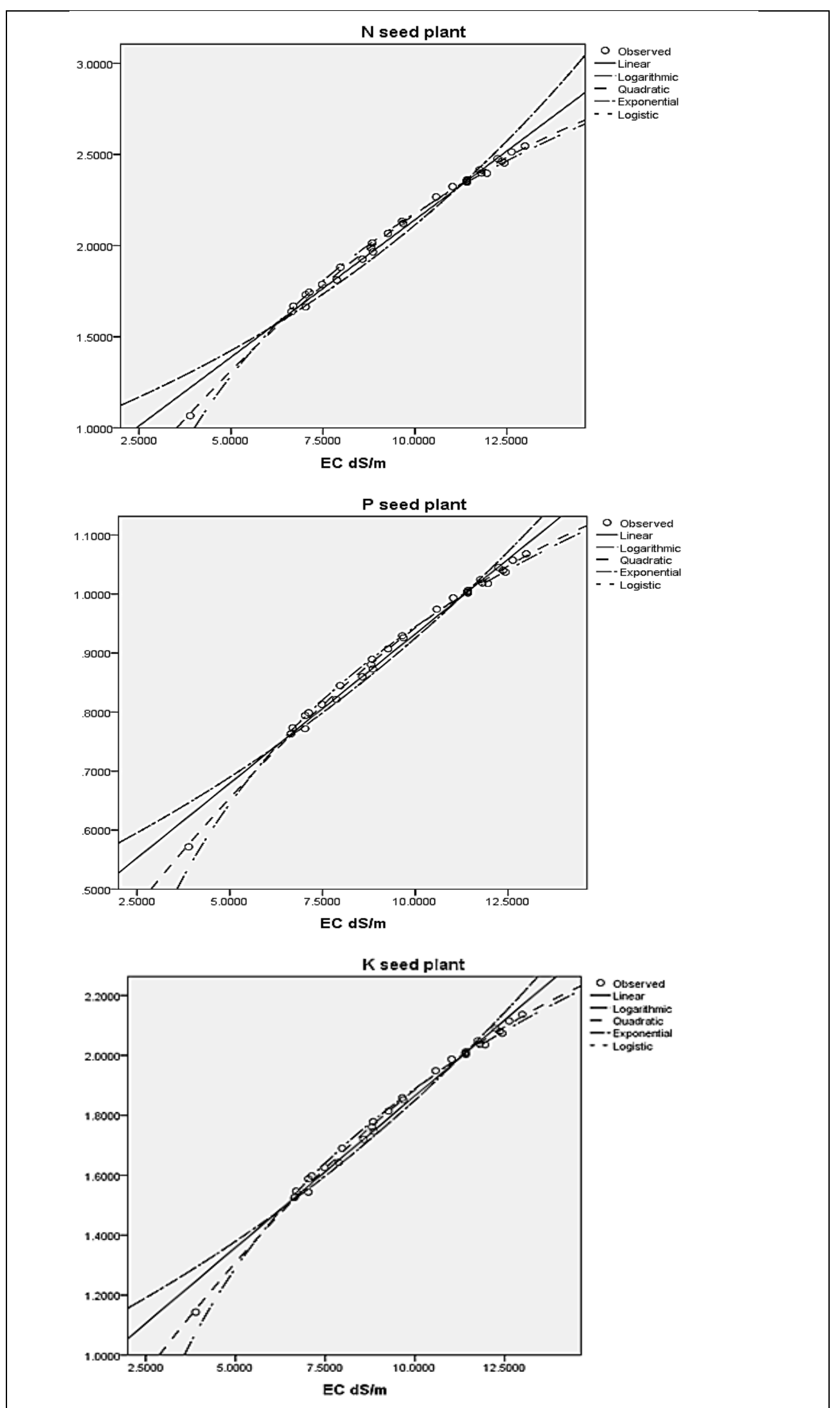

Figure (2): Relationship between Ec (dS/m) and concentration $\mathrm{N}, \mathrm{P}, \mathrm{K} \mathrm{mg} \mathrm{kg}^{-1}$ in seeds. 


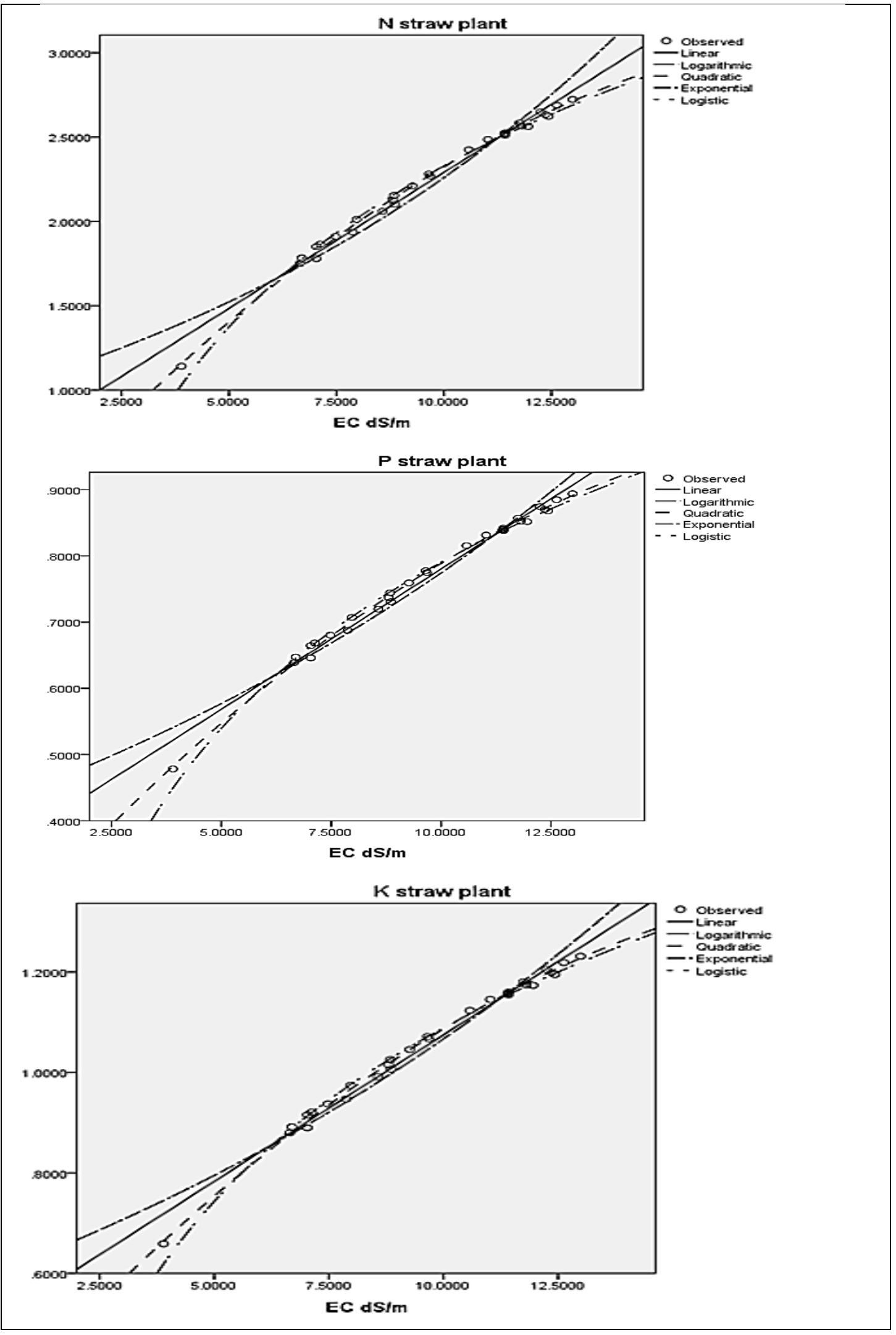

Figure (3): Relationship between Ec (dS/m) and available $\mathrm{N}, \mathrm{P}, \mathrm{K} \mathrm{mg} \mathrm{kg}^{-1}$ in straw. 


\section{Conclusion:}

Soil salinity is a threat world-wide to agricultural production and ecosystems because it reduces plant growth and microbial functioning. The effects of salinity and soil water content on soil nutrients have been studied extensively, but usually separately, in saline soils, the water content also influences the salt concentration in the soil solution (osmotic potential), the study of interaction between soil water content and salinity on soil nutrients is needed. Further in the field, soil salinity and water content are not constant in time and space.

\section{REFERENCES}

Abou Kota, M. (2012). Distribution of salinity and nutrients in soils of Egypt and Tunisia under recently environmental changes. M. Sc. Thesis. Institute of African Research and Studies. Cairo Univ. Egypt.

Abou Kota, M. (2016). Spatial modeling and prediction of soil salinity using SALTMED in A GIS environment in Egypt and Ethiopia. Ph. D. Thesis. Institute of African Research and Studies. Cairo Univ. Egypt.

Allison, L., L. Richards, R. Reeve, L. Bernstem, A. Bower, J. Brown, M. Fireman, J. Hatcher, H. Hayward, G. Pearson and L. Wilcox (1954). Diagnosis and improvement of saline and alkali soils. Untied staff salinity laboratory staff. L.A. Richards (Editor). Agriculture Handbook: 60. U.S. Department of Agriculture.

Bower, C., R. Reitemeier and M. Fireman (1952). Exchangeable cation analysis of saline and alkali soils. Soil Sci. 73:251-261, illus.

Chapman, D. D. and P. E. Pratt (1961). Methods of analysis for soil, plant and waters Univ. of California, USA.
Chapman, V. (1975). The salinity problem in general, its importance and distribution with special reference to natural halophytes. In: A. PoljakoffMayber, and J. Gale (eds), Plants in Saline Environments, Springer-Verlag, New York. pp. 7-21.

Epstein, E., J. Norlyn, D. Rush, R. Kings, D. Kelly, D. Cunningham and A. Worna (1980). Saline culture of crops. A general approach. Science 210:399404.

Genc, Y., G. Mcdonald and M. Tester (2007). Reassessment of tissue $\mathrm{Na}^{+}$ concentration as a criterion for salinity tolerance in bread wheat. Plant Cell Environ., 30: 1486 -1498.

Holman, G. and G. Elliott (1983). Chemical analysis of ecological materials. Lab. Proc., 32: 91.

Hu, Y. and U. Schmidlter (2005). Drought and salinity: A comparison of their effects on the mineral nutrition of plants. J. Plant Nutr. Soil Sci. 168: 541549.

Hu, Y., G. Dieter and S. Urs (2017). Interactive effects of nutrients and salinity and drought on wheat growth.

Jackson, M. (1967). Soil chemical analysis. Prentic Hall, Ladia Private, LTD., New Delhi.

Lindsay, W. and W. Norvell (1978). Development of DTPA soil test for $\mathrm{Zn}$, Mn and Cu. Soil Sci. Soc. Am. J. 24: 241.

McDonald, G., W. Bovill, J. Taylor and R. Wheeler (2015). Responses to phosphorus among wheat genotypes. Crop Pasture Sci., 66: 430-444.

Munns, R. and M. Tester (2008). Mechanisms of salinity tolerance. Annu. Rev. Plant Biol., 59: 651-681.

Oldeman, L., R. Hakkeling and W. Sombroek (1990). World map of the status of human- induced soiled gradation: an explanatory note. 
Olsen, S., C. Cole, F. Watanable and L. Dean (1954). Estimation of available phosphorus in soils by extraction with sodium bicarbonate. U.S. Dept. Agric. Circular No. 939.

Osborne, L. and Z. Rengel (2002). Genotypic differences in wheat for uptake and utilisation of $P$ from iron phosphate. Crop Pasture Sci., 53: 837-844.

Page, A., R. Miller and D. Keeney (1982). Methods of soil analysis. Part 2. Chemical and Microbiological Properties. 2nd (Ed.). Amer. Soc. Of Agronomy. Madison, Wisconsin, USA.

Piper, C. (1950). Soil and Plant Analysis. Inter. Sci. Publisher, Inc., New York, USA.

Prakash, R., S. Sushil, R. Vinay, J. Vimal and M. Sunil (2010). Impact of salt stress on nutrient uptake and growth of cowpea. Braz. J. Plant Physiol., 22 (1): 43-48.

Rahnama, A., R. Munns, K. Poustini and M. Watt (2011). A screening method to identify genetic variation in root growth response to a salinity gradient. J. Exp. Bot., 62: 69-77.

Reitemeier, R. (1943). Semi microanalysis of saline soil solutions. Indus. and Engin. Chem., Analyt. Ed. 15:393-402, illus.

Rodriguez-Navarro, A. and F. Rubio (2006). High affinity potassium and sodium transport systems in plants. $J$. Exp. Bot., 57: 1149 - 1160.

Saqib, M., J. Akhtar, G. Abbas and M. Nasim (2013). Salinity and drought interaction in wheat (Triticum aestivum L.) is affected by the genotype and plant growth stage. Acta Physiol. Plant., 35: 2761-2768.

Saqib, M., C. Zörb, Z. Rengel and S. Schubert (2005). The expression of the endogenous vacuolar $\mathrm{Na}^{+} / \mathrm{H}^{+}$ antiporters in roots and shoots correlates positively with the salt resistance of wheat (Triticum aestivum L.). Plant Sci., 169: 959-965.

Schoonover, W. (1952). Examination of soils for alkali extension service. University of California, Berkeley, California (Mimeographed).

Schwenke, G., S. Simpfendorfer and B. Collard (2015). Confirmation of chloride deficiency as the cause of leaf spotting in durum wheat grown in the Australian northern grains region. Crop Pasture Sci., 66: 122-134.

Shamaya, N. (2014). Genetic Studies of Salinity Tolerance in Wheat. Master's Thesis, The University of Adelaide, Adelaide, Australia, 2014.

SPSS, (2015). Command syntax reference. Chicago. Illinois: SPSS 20.0 Inc. 2015.

UNEP. (2007). Global EnvironmentOutlook4. Malta.

Van Reeuwijk, L. (1993). Procedures for Soil Analysis. CIP- Gegevens Koninklijke Bibliotheek, Den Haag, Wageningen: International Soil Reference and Information Centre. Technical Paper I International Soil Reference and Information Centre. ISSN 0923-3792: No. 9. Trefw.: Bodemkunde. ISRIC. Fourth Edition.

Wright, C. (1939). Soil Analysis. Thomas Murby Co., London.

Zaicou, C., B. Curtis, H. Dhammu, S. Ellis, D. Jorgensen, S. Miyan, S. Penny, B. Shackley, and D. Sharma (2008). Wheat Variety Guide 2008 Western Australia; Department of Agriculture and Food (Western Australia): Perth, Australia. 
تأثير ملوحة التربة علي إمتصاص المغذيات الكبري الميسرة بواسطة نبات القـح

\author{
فاطمة العجيزي ، محمد السيد ابوقوطه
}

قسم كيمياء وطبيعية الاراضي - معهة بحوث الاراضي والمياه والبيئة - مركز البحوث الزراعية البية

الملخص العربى

تعتبر ملوحة التربة في مصرهي المعوق الأساسي لتنمية القطاع الزراعي. في العقود القليلة الماضية ، وقد بذل

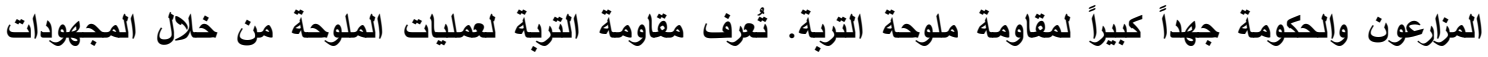

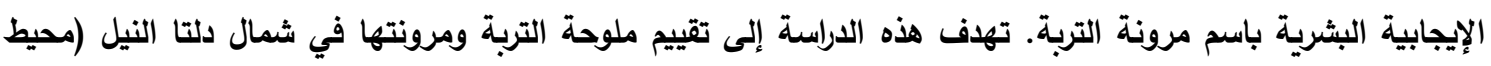

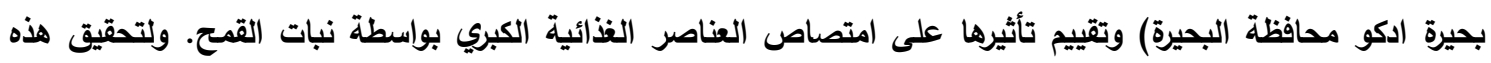

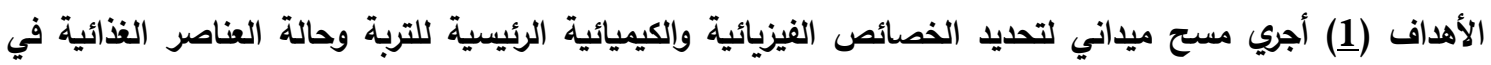

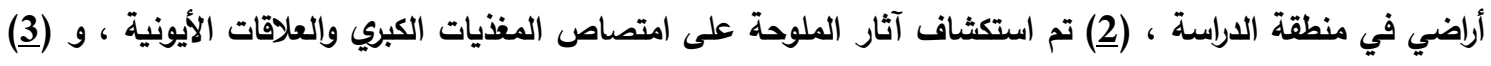

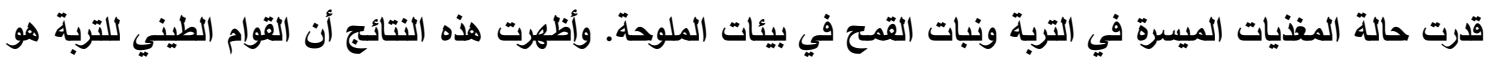

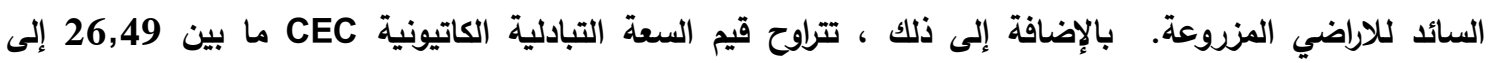
Cmolc kg-133,03 ، و CaCO 15,64٪. وقد تميزت الكاتيونات الذائبة في مستخلص عجينة التربة المشبعة بسيادة كاتيون الصوديم يلية الكاليسوم

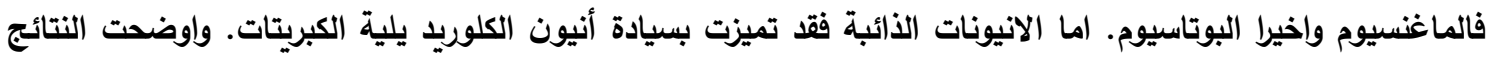

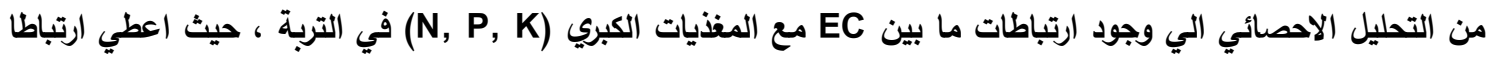

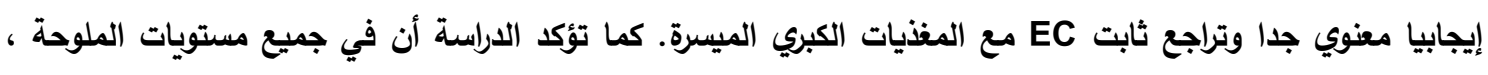

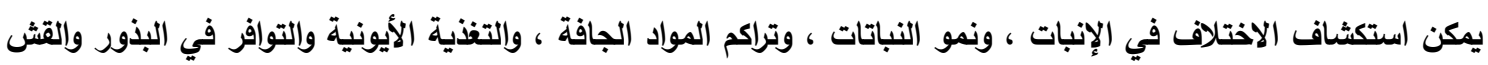
بثكل أفضل في تحديد قدرة التحمل لأصناف القدح.

السادة المحكمين

أ.د/ حسنى حسين حسونة مركز البحوث الزراعية

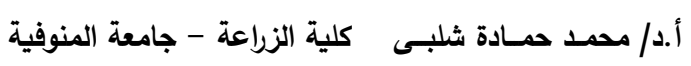


